\title{
Thyroid Dysfunction in Chronic Renal Failure
}

\author{
A STUDY OF THE PITUITARY-THYROID AXIS AND PERIPHERAL \\ TURNOVER KINETICS OF THYROXINE AND TRIIODOTHYRONINE
}

\author{
Victoria Sy Lim, Victor S. Fang, Adrian I. Katz, and Samuel Refetoff \\ From the Departments of Medicine, Michael Reese Hospital and University of Chicago Pritzker \\ School of Medicine, Chicago, Illinois 60616
}

A B S T R A C T Thyroid function was evaluated in 46 patients with end-stage kidney disease and 42 normal subjects. Patients were studied before and after the institution of maintenance hemodialysis (HD) and after renal transplantation (RT). Serum total triiodothyronine concentrations $\left(\mathrm{TT}_{3}, \mathrm{ng} / 100 \mathrm{ml}\right.$, mean $\left.\pm \mathrm{SD}\right)$ were $63 \pm 17$ and $83 \pm 22$ in the non-HD and HD groups, respectively. Values from normal subjects were $128 \pm 25$ and from RT patients $134 \pm 20$. The $\mathrm{TT}_{3}$ was in the hypothyroid range ( $<78 \mathrm{ng} / 100 \mathrm{ml} ; 2 \mathrm{SD}$ below normal mean) in $80 \%$ of non-HD and $43 \%$ of HD patients. Mean serum total thyroxine concentration $\left(\mathrm{TT}_{4}\right)$, although within the normal range, was lower than the control value. $\mathrm{T}_{4}$-binding globulin capacity was also slightly lower but the difference was not statistically significant. Among patients whose $\mathrm{TT}_{4}$ was $1 \mathrm{SD}$ below the normal mean, the free $\mathrm{T}_{4}$ index was equally depressed, suggesting that factors other than decreased binding capacity might be responsible for the low $\mathrm{TT}_{4}$. In addition, there was a $37 \%$ incidence of goiter. Mean serum thyroid-stimulating hormone (TSH) was not elevated and the TSH response to thyrotropinreleasing hormone (TRH) was distinctly blunted, suggesting the possibility of pituitary dysfunction as well. In vivo ${ }^{125} \mathrm{I}-\mathrm{L}-\mathrm{T}_{4}$ and ${ }^{131} \mathrm{I}-\mathrm{L}-\mathrm{T}_{3}$ kinetics during 0.2 $\mathrm{mg} /$ day of $\mathrm{L}-\mathrm{T}_{4}$ replacement showed marked reduction in $\mathrm{T}_{3}$ turnover rate in the uremic patients, both before and during $\mathrm{HD}$; the values $\left(\mu \mathrm{g} \mathrm{T}_{3} /\right.$ day, mean $\left.\pm \mathrm{SD}\right)$ for the different groups were as follows: normal, $33.8 \pm 6.1$; non-HD, $13.5 \pm 2.6$; HD, $12.9 \pm 3.1$; and RT, 30.3 \pm 7.1 . The low $\mathrm{T}_{3}$ turnover rate was due to impaired extrathyroidal conversion of $\mathrm{T}_{4}$ to $\mathrm{T}_{3}$. The mean per-

This work was presented in part at the 50th Annual Meeting of the American Thyroid Association, St. Louis, Mo., 18-21 September 1974, and at the 6th International Congress of Nephrology, Florence, Italy, 8-12 June 1975.

Received for publication 21 May 1976 and in revised form 25 April 1977. cent $\pm S D$ of metabolized $T_{4}$ converted to $T_{3}$ was $37.2 \pm 5.8$ in normal subjects, $15.7 \pm 3.1$ in non-HD, $12.8 \pm 1.7$ in $\mathrm{HD}$, and $34.0 \pm 14.7$ in $\mathrm{RT}$ patients. In contrast, thyroidal $\mathrm{T}_{3}$ secretion rate was not different between the control and the three patient groups. Thus, it appears that uremia affects thyroid function at several levels: (a) subnormal pituitary $\mathrm{TSH}$ response to TRH; $(b)$ possible intrathyroidal abnormalities as suggested by slightly decreased $\mathrm{TT}_{4}$ and high incidence of goiter; and (c) abnormal peripheral generation of $T_{3}$ from $T_{4}$. Restoration of renal function with RT resulted in normalization of all parameters of thyroid function with the exception of blunted or absent $\mathrm{TSH}$ response to $\mathrm{TRH}$. The latter may be a direct consequence of glucocorticoid administration.

\section{INTRODUCTION}

Patients with chronic renal failure often exhibit clinical features and laboratory findings suggestive of hypothyroidism. Despite extensive studies, thyroid status in uremia is still inconclusive due to the complexity of the system studied. For example, thyroidal radioiodide uptake is decreased because of reduced renal iodide clearance $(1,2)$. The serum hormonal concentration may be altered by changes in the binding capacity of serum proteins $(3,4)$, and abnormal serum constituents in uremia were thought to displace thyroid hormone from its protein-binding sites (5). Heparin, a standard hemodialysis (HD) ${ }^{1}$ medication, has been shown to increase serum free thyroxine concentration $(6,7)$. Peritoneal dialysis is an effective way of

\footnotetext{
${ }^{1}$ Abbreviations used in this paper: $\mathrm{HD}$, hemodialysis; RT, renal transplantation; $\mathrm{TT}_{3}$, serum total triiodothyronine; $\mathrm{TT}_{4}$ serum total thyroxine; $\mathrm{T}_{3}$, triiodothyronine; $\mathrm{T}_{4}$, thyroxine; FTI, free thyroxine index; TBG, thyroxine-binding globulin; $\mathrm{TSH}$, thyroid-stimulating hormone; TRH, thyrotropin-releasing hormone; MCR, metabolic clearance rate; $\mathrm{D}$, turnover rate.
} 
removing thyroid hormones from the circulation $(8,9)$. Goiter may be induced by the high serum level of inorganic iodide $(1,2,10)$ or retention of goitrogenic substances normally excreted by the kidney (11). Finally, malnutrition may be a contributing factor in altering thyroid function tests (12).

This communication presents the results of our attempts to study systematically the pituitary-thyroid axis as well as the peripheral metabolism of thyroid hormones in 46 patients with irreversible renal failure, before and during HD, and after renal transplantation (RT). Since recent studies from our laboratory (13) and by others (14-16) have demonstrated a reduction in the serum concentration of total triiodothyronine $\left(\mathrm{TT}_{3}\right)$, and since more than half of the circulating triiodothyronine $\left(\mathrm{T}_{3}\right)$ is derived from conversion of thyroxine $\left(T_{4}\right)$ to $T_{3}$ in the periphery (17-19), emphasis was placed on the study of this particular pathway of $\mathrm{T}_{4}$ metabolism. Additional studies include measurements of serum concentrations of total thyroxine $\left(\mathrm{TT}_{4}\right)$, $\mathrm{TT}_{3}$, free thyroxine index (FTI), thyroxine-binding globulin (TBG) capacity, thyroid autoantibodies, and thyroid-stimulating hormone (TSH) as well as TSH response to thyrotropin-releasing hormone (TRH). The results indicate that uremia affects thyroid function in several ways, the most important of which is a profound impairment of extrathyroidal conversion of $T_{4}$ to $T_{3}$ resulting in a selective reduction in serum $\mathrm{TT}_{3}$.

\section{CLINICAL MATERIAL}

46 patients ( 26 men and 20 women) with end-stage kidney disease were studied. Their ages ranged from 20 to $58 \mathrm{yr}$. The etiology of their renal failure included hypertensive nephrosclerosis, chronic glomerulonephritis, polycystic kidney disease, interstitial nephritis, and epithelial cell disease with glomerulosclerosis. 20 patients were studied before institution of HD, 37 during HD, and 11 after successful RT. 17 patients were studied more than once as they went through the various stages of treatment. At the time of this study, the mean duration of dialysis was 15 mo (range, 2-30 mo). Hemodialysis was performed three times weekly with EX-23 or EX-25 coil dialyzers. Of those patients studied before entrance into the dialysis program, blood samples were obtained during their clinic visits. In patients studied during maintenance HD, blood was routinely sampled immediately before HD and before heparin administration. After RT, blood samples were obtained periodically throughout the recovery phase, until thyroid function had either returned to normal or stabilized, representing a period of at least 6 mo. As both $\mathrm{TT}_{4}$ and $\mathrm{TT}_{3}$ increased progressively, only values that have reached a stable plateau were used in the computation of mean and standard deviation for this particular group. All renal failure patients received aluminum hydroxide, multivitamins, folic acid, and ferrous sulfate. In addition, many patients required antihypertensive medications including methyldopa, hydralazine, and propranolol. Patients who received Dilantin and androgens were excluded from this study. Diuretics were not prescribed. The RT subjects received prednisone and azathioprine in various doses. The control group consisted of 42 healthy subjects including laboratory personnel and blood donors. Their age and sex distribution were comparable to those of the patients.

The experimental protocol was approved by the Committee on Human Experimentation and the Committee on the Use of Radioisotopes of the University of Chicago Hospitals. Informed written consent was obtained from the patients as well as from the normal volunteers.

\section{METHODS}

Thyroid function tests. Serum $\mathrm{TT}_{4}$ was measured by the competitive binding procedure and the FTI was calculated (20). The $\mathrm{T}_{4}$-binding capacity of TBG was measured by saturation (4) and the concentration of serum $\mathrm{TT}_{3}$ by double-antibody precipitation radioimmunoassay (21). The $\mathrm{T}_{3}$ antiserum was supplied by Dr. Gerald Burke, Cook County Hospital, Chicago, Ill. The characteristics of this antiserum have been previously described (21). The antibody was produced in the rabbit by immunization with $\mathrm{T}_{3}$ coupled to human serum albumin; $T_{3}$ was displaced from serum TBG with 8-anilino-1-naphthalene sulfonic acid. The method was sensitive to detect $10 \mathrm{ng} \mathrm{T}_{3} / 100 \mathrm{ml}$ of serum (21). The intra- and inter-assay coefficients of variation were $<5$ and $15 \%$, respectively. Both $\mathrm{T}_{4}$ and $3,3^{\prime}, 5^{\prime}$-triiodo-L-thyronine (reverse $T_{3}$ ) in amounts equivalent to $50 \mu \mathrm{g} / 100 \mathrm{ml}$ and $1,000 \mathrm{ng} / 100 \mathrm{ml}$ of serum did not cross-react with $\mathrm{T}_{3}$ in the radioimmunoassay. Further, 95-102\% of known amounts of $T_{3}$ added to the serum of normal and uremic subjects were recovered. Serum concentration of TSH was also measured by the double-antibody precipitation radioimmunoassay (22) with one modification, in which the antiserum was incubated with $1,000 \mathrm{U}$ of human chorionic gonadotropin at room temperature for $24 \mathrm{~h}$. The anti-human TSH serum and purified human TSH for iodination were prepared by the National Pituitary Agency and supplied by the National Institutes of Health. The human TSH standard 68/38 was supplied by the Medical Research Council, London, England. Luteinizing hormone in amounts equivalent to $500 \mathrm{ng} / \mathrm{ml}$ (LER-907) did not interfere with the TSH assay. Thyroglobulin and thyroid microsomal antibodies were determined by the sheep erythrocyte hemagglutination assay (23). For each test, the average value of several determinations obtained from the same patient was used in calculating the means and standard deviations of each group.

Estimation of thyroid gland size and iodine content. The size and consistency of the thyroid gland was assessed independently by two of us (V. S. Lim and S. Refetoff). The iodine content of the gland was estimated by fluorescent scanning (24).

TRH stimulation test. The test was performed during the morning in the fasting state in seven normal subjects and seven HD and three RT patients. For the HD patients, the test was carried out on the days without dialysis; for the RT patients, it was done 8-18 mo after restoration of renal function. Two basal blood samples were obtained $30 \mathrm{~min}$ apart before the intravenous injection of $400 \mu \mathrm{g}$ of synthetic TRH (Abbott Laboratories, North Chicago, Ill.). Additional blood samples were obtained $15,30,45,60,90,120$, and 180 min after TRH administration; TSH was measured in all samples but $\mathrm{TT}_{3}$ was measured only in samples obtained immediately before and $180 \mathrm{~min}$ after TRH.

Peripheral turnover kinetics of $T_{4}$ and $T_{3}$. The peripheral metabolism of $T_{4}$ and $T_{3}$ was studied simultaneously in 22 subjects: 5 healthy euthyroid volunteers, 12 uremic patients ( 4 before and 8 after institution of maintenance HD), and 5 patients after successful RT.

${ }^{125} \mathrm{I}-\mathrm{L}-\mathrm{Thyroxine}\left({ }^{125} \mathrm{I}-\mathrm{T}_{4}\right)$ and ${ }^{131} \mathrm{I}-\mathrm{L}$-triiodothyronine $\left.{ }^{131} \mathrm{I}-\mathrm{T}_{3}\right)$ were purchased from Industrial Nuclear Co., Inc., St. Louis, 
Mo. Their specific activities were 100 and $85 \mu \mathrm{Ci} / \mu \mathrm{g}$, respectively. The radiochemical purity of both $T_{4}$ and $T_{3}$ in the isotope preparations was tested by descending paper chromatography in tertiary amyl alcohol:hexane:ammonia (25) and found to be $>95 \%$. The labeled hormones were mixed in sterile saline containing $5 \%$ salt-poor normal human serum albumin (Cutter Laboratories, Berkeley, Calif.). The final mixture was passed through a Millipore filter (Millipore Corp., Bedford, Mass.). Each patient received $2 \mathrm{ml}$ of the saline-albumin mixture containing $10 \mu \mathrm{Ci}$ of ${ }^{125} \mathrm{I}-\mathrm{T}_{4}$ and 20 $\mu \mathrm{Ci}$ of ${ }^{131} \mathrm{I}-\mathrm{T}_{3}$. This solution was injected intravenously and blood samples were obtained from the contralateral arm before, at $5 \mathrm{~min}$, and at $2,4,6,8$, and $24 \mathrm{~h}$ after injection. Thereafter, samples were obtained every 24-48 h for another 8-10 days. The sera were stored at $-20^{\circ} \mathrm{C}$ and assayed in batches with appropriate standards. Radioactivity was determined in all serum samples. Stable $\mathrm{TT}_{4}$ and $\mathrm{TT}_{3}$ were measured in samples taken immediately before isotope injection and on days $1-3$, 5,7 , and 9; the mean value for each individual subject was used for the calculation of various kinetic parameters. In the HD patients, the isotope was injected 1 to $2 \mathrm{~h}$ after completion of HD treatment. The 24-h sample, as well as the subsequent blood samples, were obtained immediately before HD. Because of these patients' tendency to retain fluid and hemodilution, which may reduce thyroid hormone concentrations, total serum protein content was determined in every sample by refractometry and corrections were made for both $\mathrm{TT}_{4}$ and $\mathrm{TT}_{3}$ concentrations as previously described (26). We used the protein concentration in the sample taken immediately before isotopic injection as base line because that was the time most HD patients were closest to their dry weight. To suppress endogenous thyroid hormone secretion and prevent recirculation of the labeled iodine, all subjects received $0.2 \mathrm{mg}$ of L-thyroxine (Synthroid, Flint Laboratories, Deerfield, Ill.) daily, beginning 7 days before isotope injection and during the entire study. Five drops of a saturated solution of potassium iodide was given $1 / 2 \mathrm{~h}$ before the administration of labeled hormones and was continued twice daily throughout the study period.

After completion of each study, $2 \mathrm{ml}$ of each serum sample was subjected to trichloroacetic acid (TCA) precipitation and the radioactivity in the precipitates was counted for $10 \mathrm{~min}$ in a dual channel gamma spectrometer (Packard Instrument Co. Inc., Downers Grove, Ill.). Contribution of ${ }^{131}$ I in the ${ }^{125}$ I channel as well as isotope decay were corrected by inclusion of appropriate standards. Only samples with isotope contents of at least fourfold the background were used in the calculations. Dose standards were prepared by addition of $0.1 \%$ of the dose to the preinjection serum sample of each patient and were subsequently handled in a manner identical to the postinjection samples.

The serum disappearance rate of TCA-precipitable ${ }^{125} \mathrm{I}$ activity from days 1 to 10 was used to calculate the $T_{4}$ kinetics. For calculation of $\mathrm{T}_{3}$ turnover kinetics, the disappearance rate of TCA-precipitable ${ }^{131}$ I activity from days 1 to 3 was used. The fractional turnover, distribution space, and metabolic clearance rate (MCR) of $\mathrm{T}_{4}$ were calculated by the method of single compartment kinetics (27). The MCR of $\mathrm{T}_{3}$ was calculated by the noncompartmental method $(19,28)$. The turnover rate (D) of $\mathrm{T}_{4}$ and $\mathrm{T}_{3}$ was derived from the product of MCR and mean serum concentration of the respective iodothyronine. Assuming that during the study period administration of L-thyroxine completely suppressed endogenous thyroid hormone secretion, the production rate of $T_{3}$ from monodeiodination of $T_{4}$ in the peripheral tissue (percent conversion of $\mathrm{T}_{4}$ to $\mathrm{T}_{3}$ ) could be calculated (19). The percent of administered $\mathbf{T}_{4}$ absorbed was also calculated as described by Surks et al. (19).
Assuming that MCR of $\mathrm{T}_{4}$ and $\mathrm{T}_{3}$, as well as the percent of $\mathrm{T}_{4}$ to $T_{3}$ conversion in each individual, were identical before and during $T_{4}$ replacement, the $T_{3}$ produced by monodeiodination and that derived from thyroidal secretion during the basal state (before $T_{4}$ replacement) could be calculated by using serum $\mathrm{TT}_{4}$ and $\mathrm{TT}_{3}$ concentrations before $\mathrm{T}_{4}$ administration:

$\mathrm{T}_{3}$ derived from $\mathrm{T}_{4}(\mu \mathrm{mol} / \mathrm{day})$

$$
=\mathrm{T}_{4} \text { turnover }(\mu \mathrm{mol} / \text { day }) \times \frac{\% \mathrm{~T}_{4} \rightarrow \mathrm{T}_{3} \text { conversion }}{100},
$$

and

$\mathrm{T}_{3}$ derived from thyroidal secretion ( $\left.\mu \mathrm{g} / \mathrm{day}\right)$

$=$ Total $\mathrm{T}_{3}$ turnover $(\mu \mathrm{g} /$ day $)-\mathrm{T}_{3}$ derived from $\mathrm{T}_{4}(\mu \mathrm{g} /$ day $)$.

The thyroidal secretion as percent of the total $T_{4}$ turnover rate was also estimated.

Serum volume was estimated from the percent of the ${ }^{125} \mathrm{I}-\mathrm{T}_{4}$ dose present in serum $5 \mathrm{~min}$ after injection of isotopes. Previous studies have shown that the dilutions of albumin and $T_{4}$ are almost identical at this time of sampling and therefore the latter is suitable for measurement of serum volume $(29,30)$.

Statistical analysis. All grouped data were expressed as mean $\pm S D$ and were analyzed by the analysis of variance; mean square within value and paired $t$ test were used to assess the statistical difference between any two means as indicated in the text (31).

\section{RESULTS}

Thyroid function tests (Table I). The most striking abnormality in the uremic patients was a reduction in serum $\mathrm{TT}_{3}$ concentration. The mean level of the combined non-HD and HD groups, $70 \mathrm{ng} / 100 \mathrm{mg}$, was $2 \mathrm{SD}$ lower than the normal mean of $128 \mathrm{ng} / 100 \mathrm{ml}$. In fact, in 16 of 20 non-HD patients and in 16 of 37 $\mathrm{HD}$ patients, $\mathrm{TT}_{3}$ was $2 \mathrm{SD}$ below the normal mean, i.e., $<78 \mathrm{ng} / 100 \mathrm{ml}$. The mean values of $\mathrm{TT}_{4}, \mathrm{FTI}$, and TBG capacity for the two groups of uremic patients were also reduced, but none of the differences reached statistical significance, with the exception of $\mathrm{TT}_{4}$ in the HD group. Both $\mathrm{TT}_{4}$ and $\mathrm{TBG}$ capacity were highly correlated in all four groups of subjects, the correlation coefficients (not shown in the tables) being as follows: normal, $0.820(P<0.001)$; before $\mathrm{HD}$, $0.686(P<0.05)$; during HD, $0.665(P<0.01)$; and after RT, $0.827(P<0.02)$. In the two uremic groups there were 7 non-HD and $11 \mathrm{HD}$ patients whose $\mathrm{TT}_{4}$ was $<6.1 \mu \mathrm{g} / 100 \mathrm{ml}$ (1 SD below normal mean); their corresponding FTI was also depressed, being $4.9 \pm 1.5$ and $5.5 \pm 1.1$, respectively. The $\mathrm{TT}_{4} / \mathrm{TT}_{3}$ ratio was markedly elevated in the two groups of renal failure patients, suggesting a selective decrease in $\mathrm{TT}_{3}$. Despite markedly depressed $\mathrm{TT}_{3}$ and slightly low $\mathrm{TT}_{4}$, serum TSH was not elevated in either group of uremic patients, nor was there any negative correlation between $\mathrm{TT}_{3}$ and $\mathrm{TSH}$ when individual data were analyzed. Restoration of renal function by RT resulted in normalization of all thyroid function tests. The 
TABLE I

Thyroid Function Tests in Normal Subjects Compared to Uremic and Renal Transplant Patients*

\begin{tabular}{lcccccc}
\hline & TT & FTI & TBG capacity & $\mathrm{TT}_{3}$ & $\begin{array}{c}\mathrm{TT}_{\downarrow} / \mathrm{TT}_{3} \\
\text { ratio }\end{array}$ & TSH \\
\hline & $\mu g / 100 \mathrm{ml}$ & & $\mu g T_{\downarrow} / 100 \mathrm{ml}$ & $n g / 100 \mathrm{ml}$ & & $\mu l^{\prime} / \mathrm{ml}$ \\
Normal & $6.6 \pm 1.4$ & $7.1 \pm 1.0$ & $18.3 \pm 5.4$ & $128 \pm 25$ & $55 \pm 17$ & $2.8 \pm 1.2$ \\
& $(42)$ & $(42)$ & $(42)$ & $(42)$ & $(42)$ & $(42)$ \\
Range & $4.2-8.7$ & $4.5-8.5$ & $14-26$ & $80-160$ & $33-73$ & $0.1-8$ \\
Before HD & $6.2 \pm 2.5$ & $7.0 \pm 2.4$ & $16.4 \pm 3.0$ & $63 \pm 17$ & $102 \pm 43$ & $3.2 \pm 1.5$ \\
& $(16)$ & $(16)$ & $(8)$ & $(20)$ & $(16)$ & $(16)$ \\
$P \ddagger$ & $\mathrm{NS}$ & $\mathrm{NS}$ & $\mathrm{NS}$ & $<0.01$ & $<0.01$ & $\mathrm{NS}$ \\
During HD & $5.6 \pm 1.2$ & $6.6 \pm 1.5$ & $16.5 \pm 4.0$ & $83 \pm 22$ & $72 \pm 28$ & $2.7 \pm 2.5$ \\
& $(30)$ & $(30)$ & $(20)$ & $(37)$ & $(30)$ & $(28)$ \\
$P \ddagger$ & $<0.05$ & $\mathrm{NS}$ & $\mathrm{NS}$ & $<0.01$ & $<0.05$ & $\mathrm{NS}$ \\
After RT & $7.9 \pm 1.6$ & $7.8 \pm 1.1$ & $22.0 \pm 6.4$ & $134 \pm 20$ & $58 \pm 13$ & $3.3 \pm 2.1$ \\
& $(9)$ & $(8)$ & $(8)$ & $(11)$ & $(9)$ & $(7)$ \\
$P \ddagger$ & $\mathrm{NS}$ & $\mathrm{NS}$ & $\mathrm{NS}$ & $\mathrm{NS}$ & $\mathrm{NS}$ & $\mathrm{NS}$ \\
F ratio & 4.958 & 1.633 & 2.451 & 57.735 & 12.722 & 1.216 \\
Degree of freedom & $3 / 93$ & $3 / 92$ & $3 / 73$ & $3 / 106$ & $3 / 91$ & $3 / 90$ \\
$P$ & $<0.01$ & $\mathrm{NS}$ & $\mathrm{NS}$ & $<0.001$ & $<0.001$ & $\mathrm{NS}$ \\
\hline
\end{tabular}

* Values are given as mean $\pm \mathrm{SD}$; in normal subjects, the absolute range is also included. The numbers in parentheses indicate patients studied in each category. Individual values from all four groups were included and tested by the analysis of variance. The $F$ ratio, degree of freedom, and $P$ values are indicated.

$\$$ The significance of the difference between the means of each patient group and the control was tested by using mean square within value.

reciprocal changes between serum creatinine and $\mathrm{TT}_{3}$ concentration in two patients are illustrated in Fig. 1. While serum creatinine fell precipitously after RT, $\mathrm{TT}_{3}$ did not become normal until about 3-4 mo later.

Data from eight anephric patients undergoing HD were analyzed separately to determine whether total absence of renal tissue may accentuate the observed abnormalities. The means \pm SD of the various thyroid function tests in these eight patients were as follows: $\mathrm{TT}_{4}, 4.9 \pm 0.9 \mu \mathrm{g} / 100 \mathrm{ml} ; \mathrm{TT}_{3}, 78 \pm 18 \mathrm{ng} / 100 \mathrm{ml}$; and $\mathrm{TSH}, 4.4 \pm 4.5 \mu \mathrm{U} / \mathrm{ml}$. These values were not different from those of the other HD patients.

Thyroglobulin and thyroid microsomal antibodies were absent in the 14 uremic subjects tested. A positive reaction with at least one of the two antigens is usually found in $10 \%$ of an unselected population without obvious clinical evidence of thyroid dysfunction and in $85-95 \%$ of patients with autoimmune thyroid disease (23). The failure to detect antibodies in our patients suggests that autoimmune thyroid disease is not likely to be the cause of the thyroid function abnormalities observed in uremia.

Effect of $H D$ on thyroid function tests. 11 patients were studied both before and at least 2 mo after

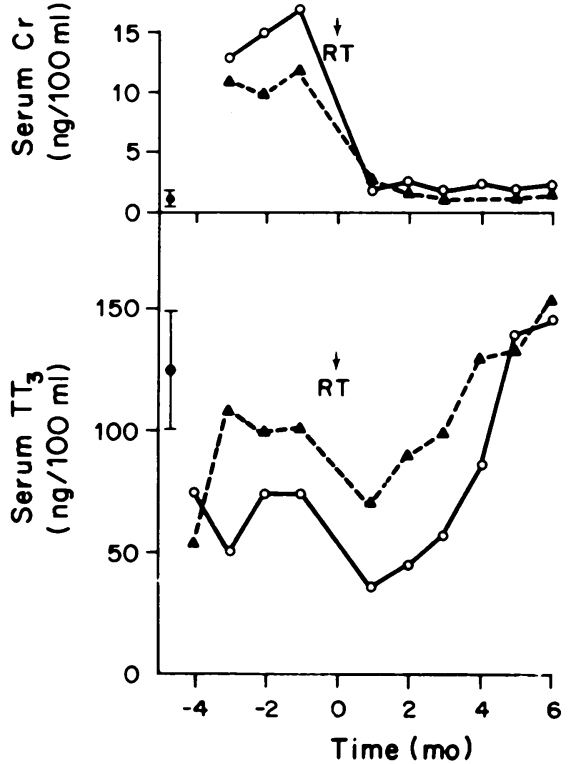

FIgURE 1 Reciprocal changes in serum creatinine and $\mathrm{TT}_{3}$ before and after RT in two patients, EM (O) and RM ( $\Delta)$. Mean \pm SD for normal subjects is represented by the bars on the left. 0 time on the abscissa corresponds to RT. 
initiation of maintenance HD. Their thyroid function tests are summarized in Table II. Hemodialysis resulted in only a slight increase in $\mathrm{TT}_{3}$ without significant change in other thyroid functions.

Thyroid gland size and iodine content. Abnormal thyroid glands were found in 9 of $24 \mathrm{HD}$ patients examined (37\%). Two had nodular goiters and the other seven had diffusely enlarged thyroid glands. 14 HD patients were randomly selected for fluorescent thyroid scanning. The thyroidal iodine content estimated by this method was slightly decreased in two, normal in six, and markedly increased in the remaining six patients.

TRH stimulation test. After TRH injection, serum TSH concentration rose rapidly in seven normal subjects, reached a peak by $30 \mathrm{~min}$, and returned to basal levels in $3 \mathrm{~h}$. Of the seven HD patients tested, one showed no increase in serum TSH concentration, four had a blunted response, and the other two showed a low normal response. In the latter, the peak was delayed until 45-60 min, and TSH levels remained elevated for more than $3 \mathrm{~h}$ (Fig. 2). The basal TSH value was normal in both the control and the uremic subjects, but the latter appeared to be lower. After TRH injection, serum $\mathrm{TT}_{3}$ concentration increased in five HD patients and was unchanged in the other two. The mean basal value was 72.1 and rose to $93.3 \mathrm{ng} /$ $100 \mathrm{ml}$, representing an increment of $28 \%$. The difference between these two means as computed by paired $t$ test was significant at $<0.05$ level. Of three RT subjects, 1 showed a blunted response and the other two failed to show any serum TSH increment (Fig. 3). Despite minimal or no serum TSH elevation, serum $\mathrm{TT}_{3}$ increased from a mean base line of 155 to $187 \mathrm{ng} /$ $100 \mathrm{ml}$, a $21 \%$ increment; the difference was not significant.

Peripheral turnover kinetics of $T_{4}$ and $T_{3}$. Table III presents data on the $T_{4}$ and $T_{3}$ metabolism in each

\section{TABLE II}

Thyroid Function Tests in Uremic Patients Studied before and 2 mo after Initiation of Maintenance Hemodialysis*

\begin{tabular}{lcccc}
\hline & $\mathrm{TT}_{4}$ & $\mathrm{FTI}$ & $\mathrm{TT}_{3}$ & $\mathrm{TSH}$ \\
\hline & $\mu g / 100 \mathrm{ml}$ & & $n g / 100 \mathrm{ml}$ & $\mu U / \mathrm{ml}$ \\
Before HD & $6.5 \pm 2.8$ & $7.2 \pm 2.7$ & $63 \pm 18$ & $4.0 \pm 3.0$ \\
& $(11)$ & $(11)$ & $(17)$ & $(14)$ \\
After HD & $6.2 \pm 1.9$ & $7.2 \pm 1.6$ & $78 \pm 19$ & $2.3 \pm 3.0$ \\
& $(11)$ & $(11)$ & $(17)$ & $(14)$ \\
$P$ & $\mathrm{NS}$ & $\mathrm{NS}$ & $<0.02$ & $\mathrm{NS}$ \\
\hline
\end{tabular}

* Values are given as mean $\pm \mathrm{SD}$. The number of patients is in parentheses. Statistical significance of difference was calculated by the paired $t$ test.

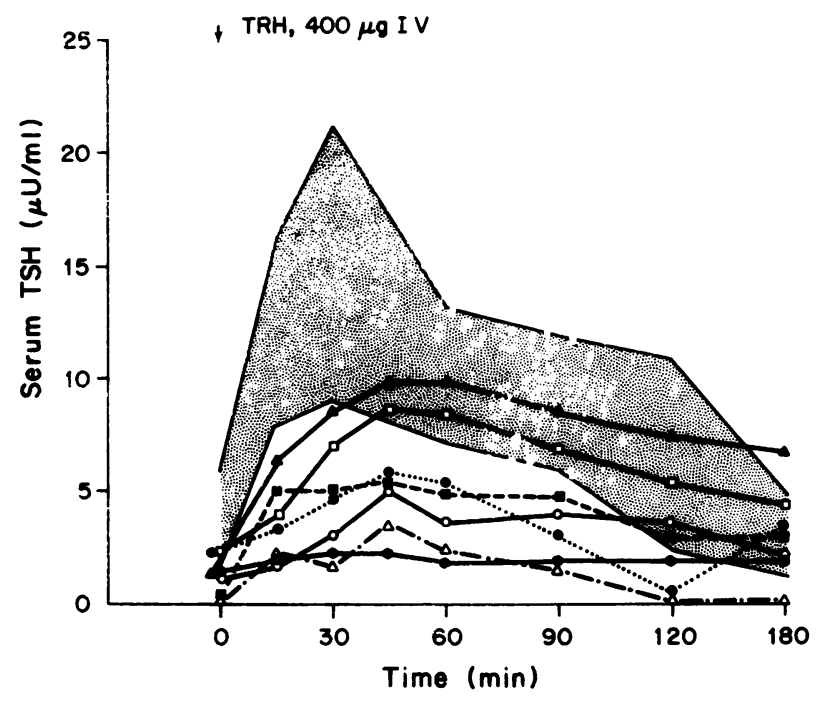

FIGURE 2 Serum TSH response to $400 \mu \mathrm{g}$ of TRH given intravenously in seven HD patients as compared to that of seven normal subjects whose ranges are represented by the shaded area.

subject studied, as well as mean values and statistical analyses. Administration of $\mathrm{L}-\mathrm{T}_{4}$ elevated to a variable extent the serum $\mathrm{TT}_{4}$ concentration in all subjects. In some, $\mathrm{TT}_{4}$ increased to above $9.4 \mu \mathrm{g} / 100 \mathrm{ml}$, the upper limit of normal. There was no correlation between the $\mathrm{TT}_{4}$ concentration before and during $\mathrm{L}-\mathrm{T}_{4}$ replacement. In contrast, the incremental rise in $\mathrm{TT}_{3}$ concentration during $\mathrm{L}-\mathrm{T}_{4}$ replacement was proportional to the pretreatment $\mathrm{TT}_{3}$ value in all subjects from the four groups, $r=0.934, P<0.001$ (Fig. 4). Thus, although serum $\mathrm{TT}_{3}$ increased after $\mathrm{L}^{-\mathrm{T}_{4}}$

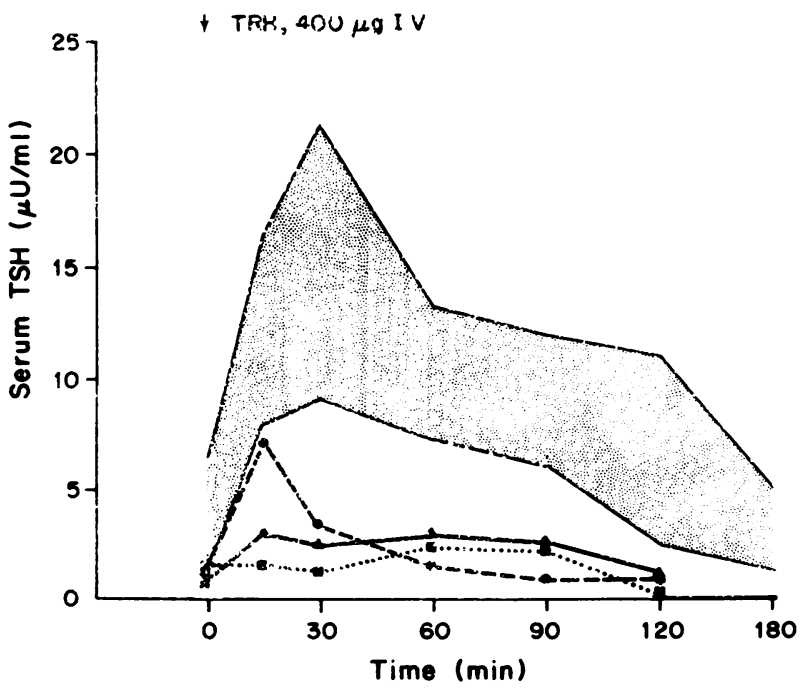

FIGURE 3 Serum TSH response to $400 \mu \mathrm{g}$ of TRH given intravenously in three RT patients. The shaded area represents the range obtained from seven normal subjects. 
TABLE III

Metabolism of $T_{4}$ and $T_{3}$ during L-T $T_{4}$ Replacement*

\begin{tabular}{|c|c|c|c|c|c|c|c|c|c|c|c|c|c|}
\hline \multirow{2}{*}{$\begin{array}{c}\text { Group and } \\
\text { patient }\end{array}$} & \multirow{2}{*}{$\begin{array}{l}\text { Creati- } \\
\text { nine }\end{array}$} & \multirow[b]{2}{*}{ Weight } & \multirow{2}{*}{$\begin{array}{c}\text { Serum } \\
\text { volume }\end{array}$} & \multicolumn{5}{|c|}{$\mathrm{T}_{4}$ metabolism } & \multirow{2}{*}{$\begin{array}{c}\mathrm{T}_{4} \\
\text { absorp- } \\
\text { tion }\end{array}$} & \multicolumn{3}{|c|}{$\mathrm{T}_{3}$ metabolism } & \multirow{2}{*}{$\begin{array}{c}T_{4} \text { to } T_{3} \\
\text { conver- } \\
\text { sion }\end{array}$} \\
\hline & & & & $\mathrm{TT}_{4}$ & $\mathbf{k}$ & DS & MCR & D & & $\mathrm{TT}_{3}$ & MCR & D & \\
\hline & $\begin{array}{c}m g / 100 \\
m l\end{array}$ & $k g$ & liters & $\begin{array}{c}\mu g / 100 \\
m l\end{array}$ & \%/day & liters & liters/day & $\mu g / d a y$ & $\%$ & $\begin{array}{c}n g / 100 \\
m l\end{array}$ & $\begin{array}{l}\text { liters/ } \\
\text { day }\end{array}$ & $\mu g / d a y$ & $\%$ \\
\hline \multicolumn{14}{|l|}{ Normal } \\
\hline D. B. & 1.0 & 70 & 3.79 & 8.3 & 11.5 & 12.8 & 1.47 & 122 & 61 & 182 & 23.4 & 42.6 & 41.7 \\
\hline T. C. & 0.8 & 59 & 3.30 & 9.2 & 9.8 & 10.1 & 0.99 & 91 & 46 & 190 & 15.4 & 29.3 & 38.5 \\
\hline F. K. & 1.1 & 77 & 3.86 & 8.6 & 9.8 & 12.4 & 1.21 & 104 & 52 & 217 & 17.3 & 37.5 & 43.1 \\
\hline W. S. T. & 1.2 & 74 & 4.64 & 8.4 & 10.9 & 12.3 & 1.34 & 113 & 56 & 148 & 21.5 & 31.8 & 33.6 \\
\hline E. S. & 0.9 & 46 & 3.39 & 11.2 & 9.2 & 11.1 & 1.02 & 114 & 57 & 181 & 15.5 & 28.0 & 29.3 \\
\hline Mean \pm SD & $1.0 \pm 0.2$ & $65 \pm 13$ & $3.80 \pm 0.53$ & $9.1 \pm 1.2$ & $10.2 \pm 0.9$ & $11.7 \pm 1.1$ & $1.21 \pm 0.21$ & $109 \pm 12$ & $54 \pm 6$ & $184 \pm 25$ & $18.6 \pm 3.6$ & $33.8 \pm 6.1$ & $37.2 \pm 5.8$ \\
\hline \multicolumn{14}{|l|}{ Before HD } \\
\hline W. S. & 11.5 & 76 & 5.02 & 9.2 & 5.9 & 18.5 & 1.10 & 101 & 51 & 70 & 17.0 & 11.9 & 14.1 \\
\hline W. A. & 6.5 & 44 & 3.03 & 10.4 & 7.9 & 12.8 & 1.01 & 105 & 53 & 105 & 10.2 & 10.7 & 12.2 \\
\hline D. $\mathbf{M}$. & 11.0 & 80 & 4.23 & 9.9 & 6.2 & 16.7 & 1.03 & 102 & 51 & 97 & 15.6 & 15.1 & 17.7 \\
\hline M. A. S. & 10.8 & 61 & 3.66 & 8.5 & 8.0 & 15.2 & 1.21 & 103 & 53 & 105 & 15.5 & 16.3 & 18.9 \\
\hline Mean \pm SD & $10.0 \pm 2.3$ & $65 \pm 16$ & $3.99 \pm 0.85$ & $9.5 \pm 0.8$ & $7.0 \pm 1.1$ & $15.8 \pm 2.4$ & $1.09 \pm 0.09$ & $103 \pm 2$ & $52 \pm 1$ & $94 \pm 17$ & $14.6 \pm 3.0$ & $13.5 \pm 2.6$ & $15.7 \pm 3.1$ \\
\hline$P \ddagger$ & $<0.01$ & NS & NS & NS & $<0.05$ & NS & NS & NS & NS & $<0.01$ & NS & $<0.01$ & $<0.01$ \\
\hline \multicolumn{14}{|l|}{ During HD } \\
\hline C. L. & 10.6 & 75 & 2.84 & 6.1 & 7.8 & 12.8 & 1.00 & 61 & 31 & 88 & 8.6 & 7.6 & 14.9 \\
\hline S. R. & 9.6 & 60 & 2.31 & 6.2 & 11.2 & 15.2 & 1.69 & 105 & 53 & 86 & 11.4 & 9.8 & 11.2 \\
\hline W. C. & 6.5 & 75 & 3.79 & 12.7 & 11.0 & 9.8 & 1.08 & 137 & 69 & 142 & 11.7 & 16.6 & 14.5 \\
\hline J. S. & 15.6 & 79 & 6.44 & 7.7 & 7.3 & 25.0 & 1.82 & 140 & 70 & 76 & 17.5 & 13.3 & 11.4 \\
\hline E. J. & 13.2 & 79 & 3.01 & 12.2 & 8.3 & 12.2 & 1.01 & 123 & 62 & 115 & 10.3 & 11.9 & 11.6 \\
\hline W. B. & 11.0 & 82 & 3.43 & 7.2 & 12.6 & 13.2 & 1.66 & 119 & 60 & 105 & 12.2 & 12.8 & 12.9 \\
\hline R. J. & 17.4 & 71 & 6.40 & 8.2 & 9.8 & 20.8 & 2.05 & 168 & 84 & 94 & 16.8 & 15.8 & 11.2 \\
\hline M. T. & 13.8 & 76 & 4.25 & 12.7 & 8.6 & 11.2 & 0.96 & 122 & 61 & 137 & 11.1 & 15.2 & 14.9 \\
\hline Mean $\pm S D$ & $12.2 \pm 3.5$ & $75 \pm 7$ & $4.06 \pm 1.57$ & $9.1 \pm 2.9$ & $9.6 \pm 1.9$ & $15.0 \pm 5.2$ & $1.41 \pm 0.44$ & $122 \pm 31$ & $61 \pm 15$ & $105 \pm 24$ & $12.5 \pm 3.1$ & $12.9 \pm 3.1$ & $12.8 \pm 1.7$ \\
\hline$P \ddagger$ & $<0.01$ & NS & NS & NS & NS & NS & NS & NS & NS & $<0.01$ & $<0.01$ & $<0.01$ & $<0.01$ \\
\hline \multicolumn{14}{|l|}{ After RT } \\
\hline J. R. & 2.3 & 75 & 5.14 & 8.7 & 13.6 & 12.1 & 1.64 & 142 & 71 & 154 & 16.3 & 25.1 & 21.1 \\
\hline R. T. & 2.1 & 99 & 4.76 & 11.5 & 8.3 & 13.1 & 1.10 & 127 & 64 & 146 & 14.6 & 21.3 & 20.1 \\
\hline M. S. & 1.5 & 66 & 3.31 & 12.0 & 10.6 & 11.9 & 1.25 & 150 & 75 & 193 & 19.4 & 37.4 & 29.8 \\
\hline S. W. & 0.9 & 75 & 3.97 & 10.0 & 8.6 & 11.1 & 0.95 & 95 & 47 & 194 & 19.0 & 36.9 & 46.6 \\
\hline N. G. & 1.2 & 61 & 2.63 & 8.7 & 8.4 & 9.5 & 0.80 & 70 & 35 & 152 & 20.2 & 30.7 & 52.4 \\
\hline Mean $\pm S D$ & $1.6 \pm 0.6$ & $75 \pm 16$ & $3.96 \pm 1.02$ & $10.2 \pm 1.5$ & $9.9 \pm 2.3$ & $11.5 \pm 1.4$ & $1.15 \pm 0.32$ & $117 \pm 34$ & $58 \pm 17$ & $168 \pm 24$ & $17.9 \pm 2.4$ & $30.3 \pm 7.1$ & $34.0 \pm 14.7$ \\
\hline$P \ddagger$ & NS & NS & NS & NS & NS & NS & NS & NS & NS & NS & NS & NS & NS \\
\hline $\mathrm{F}$ ratio & 33.623 & & & 0.313 & 3.189 & 2.014 & 0.567 & 0.599 & 0.587 & 19.280 & 5.496 & 27.341 & 15.092 \\
\hline \multicolumn{14}{|l|}{ Degree of } \\
\hline freedom & $3 / 18$ & & & $3 / 18$ & $3 / 18$ & $3 / 18$ & $3 / 18$ & $3 / 18$ & $3 / 18$ & $3 / 18$ & $3 / 18$ & $3 / 18$ & $3 / 18$ \\
\hline$P$ & $<0.001$ & & & NS & $<0.05$ & NS & NS & NS & NS & $<0.0001$ & $<0.01$ & $<0.0001$ & $<0.0001$ \\
\hline
\end{tabular}

* Individual values from all four groups were analyzed together by the method of analysis of variance and reported as $F$ ratio, degree of freedom, and $P$ values. $\ddagger$ The difference between the means of each patient group and the controls $(P)$ were analyzed by using the mean square within value.

treatment in all uremic patients, in most it remained below the normal mean of $128 \mathrm{ng} / 100 \mathrm{ml}$. In normal subjects and RT patients, serum $\mathrm{TT}_{3}$ increased often to above $160 \mathrm{ng} / 100 \mathrm{ml}$, the upper limit of normal. Individual fluctuations in serum $\mathrm{TT}_{4}$ and $\mathrm{TT}_{3}$ throughout the turnover study showed no distinct trend, indicating that a steady state has been achieved.

Also shown in Table III is the absorption rate of exogenous $\mathrm{T}_{4}$ in uremic subjects, which ranged from 31 to $84 \%$. These values are compatible with data obtained by Surks et al. (19) and by Hays (32) in normal subjects. The RT patients also absorbed L- $\mathrm{T}_{4}$ normally.

The parameters of $T_{4}$ metabolism were similar in all groups studied with the exception of a decrease in $\mathrm{K}$ and a slightly higher DS in the non-HD uremic patients. This is probably due to the distribution of the labeled hormone into a large extracellular volume. As a result of these reciprocal changes, the $\mathrm{T}_{4}$ turnover rate remained within normal limits. The MCR and D of the HD uremic patients were normal, but there was a trend for the fractional turnover to be lower and for the DS to be higher. The two patients who had the largest distribution space also had the largest serum volume. The $T_{4}$ kinetics of $R T$ subjects were similar to that of controls.

In contrast to the $T_{4}$ kinetics, $T_{3}$ kinetics were distinctly abnormal in both groups of uremic patients. The mean serum $\mathrm{TT}_{3}$ concentration, $\mathrm{T}_{3}$ turnover rate, and percent $T_{4}$ to $T_{3}$ conversion were drastically 

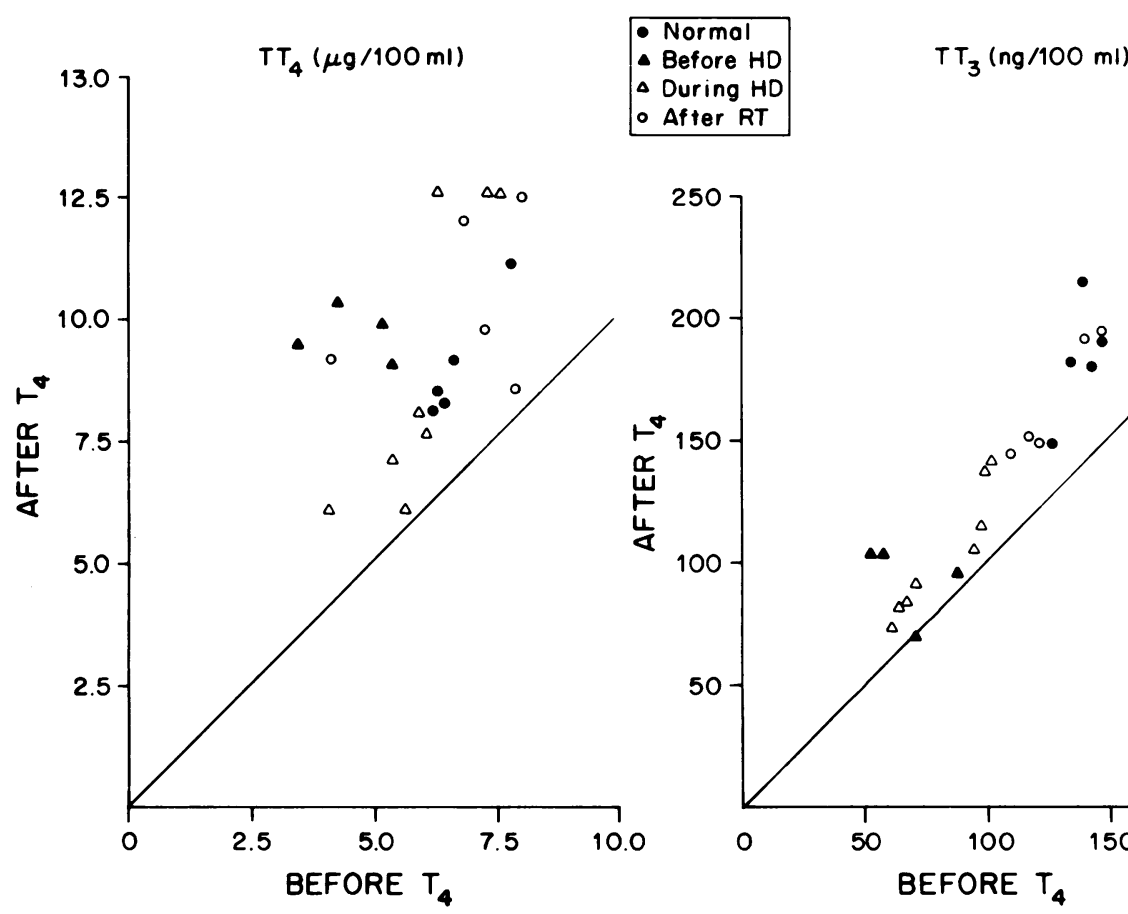

FIGURE 4 The relationship of serum concentrations of $\mathrm{TT}_{4}$ (left) and $\mathrm{TT}_{3}$ (right) before and after $\mathrm{L}-\mathrm{T}_{4}$ replacement in the control and the three experimental groups. All received $0.2 \mathrm{mg}$ of $\mathrm{L}_{-} \mathrm{T}_{4}$ orally every day for 7 days before the experiment and throughout the study period. The pretreatment values are means of two to four samples. The posttreatment values are means of six samples taken during the experimental period after being on thyroid replacement for 7 days. The increment in $\mathrm{TT}_{3}$ is proportional to the pretreatment level in all 4 groups of subjects $(r=0.934, P<0.001)$, whereas $\mathrm{TT}_{4}$ concentration before and after replacement did not show any significant correlation.

reduced. The MCR also tended to be lower, but the difference was significant only in the HD group. All subjects in the two uremic groups had $\mathrm{D}$ and percent $\mathrm{T}_{4}$ to $\mathrm{T}_{3}$ conversion at least $2 \mathrm{SD}$ below the normal means, and the latter was reduced to about a third of normal. After RT, the MCR, D, and percent of metabolized $\mathrm{T}_{4}$ converted to $\mathrm{T}_{3}$ became normal.

To determine the thyroidal contribution to $\mathrm{T}_{3}$ metabolism by direct secretion of $\mathrm{T}_{3}$, data from the MCR of $T_{4}$ and $T_{3}$ during $L-T_{4}$ replacement and the serum concentration of $\mathrm{TT}_{4}$ and $\mathrm{TT}_{3}$ before $\mathrm{L}-\mathrm{T}_{4}$ replacement were used as described in the section on Methods and the results are summarized in Table IV. The mean thyroidal secretion of $T_{3}$ ranged from 1.7 to $3.7 \mu \mathrm{g} /$ day and was not significantly different in the various groups. However, due to decreased peripheral conversion of $T_{4}$ to $T_{3}$ in uremia, the relative contribution of direct thyroidal $\mathrm{T}_{3}$ secretion to total $\mathrm{T}_{3}$ turnover was greater, being $33.5 \pm 10.5 \%$ in the non-HD and $16.6 \pm 10.5 \%$ in the HD patients. The former was significantly higher than that of normal controls $(6.9$ $\pm 4.4 \%$ ).
Table IV also lists $\mathrm{D}$ for $\mathrm{T}_{4}$ and $\mathrm{T}_{3}$ in the basal state (without $\mathrm{L}-\mathrm{T}_{4}$ replacement). $\mathrm{T}_{4}$ metabolism was not different from the controls whereas $T_{3} D$ was markedly decreased in both non-HD and HD patients.

\section{DISCUSSION}

These studies demonstrate that disturbances of thyroid function, the most important of which is a marked reduction in serum $\mathrm{TT}_{3}$ concentration, are common in chronic renal failure. Decreased serum $\mathrm{TT}_{3}$ was previously reported by us (13) and by Silverberg et al. (14) and was subsequently confirmed by several other investigators $(15,16,33,34)$. Circulating $\mathrm{TT}_{3}$ was reduced into the hypothyroid range $(<78 \mathrm{ng} / 100 \mathrm{ml})$ in $80 \%$ of the non-HD and $43 \%$ of the HD patients. While $\mathrm{L}-\mathrm{T}_{4}$ administration effectively raised serum $\mathrm{TT}_{4}$ to levels often above the normal range, $\mathrm{TT}_{3}$ remained subnormal. This observation, coupled with the high $\mathrm{TT}_{4} / \mathrm{TT}_{3}$ ratio in the serum, suggested that low $\mathrm{TT}_{3}$ concentration in uremia may represent a selective deficiency. In our patient population, low $\mathrm{TT}_{3}$ could 
TABLE IV

Turnover Rate of $T_{4}$ and $T_{3}$ and Thyroidal Secretion of $T_{3}$ before L- $T_{4}$ Replacement*

\begin{tabular}{|c|c|c|c|c|c|c|}
\hline \multirow{3}{*}{$\begin{array}{c}\begin{array}{c}\text { Group and } \\
\text { patient }\end{array} \\
.\end{array}$} & \multicolumn{2}{|c|}{$\mathrm{T}_{4}$ metabolism } & \multicolumn{2}{|c|}{$\mathrm{T}_{3}$ metabolism } & & \\
\hline & \multirow{2}{*}{$\frac{\mathrm{TT}_{4}}{\mu \mathrm{g} / 100 \mathrm{ml}}$} & \multirow{2}{*}{$\frac{\mathrm{D}}{\mu \mathrm{g} / \mathrm{day}}$} & \multirow{2}{*}{$\frac{\mathrm{TT}_{3}}{n g / 100 \mathrm{ml}}$} & \multirow{2}{*}{$\frac{\mathrm{D}}{\mu g / d a y}$} & \multicolumn{2}{|c|}{$T_{3}$ secreted by thyroid } \\
\hline & & & & & $\mu g / d a y$ & $\%$ of $D\left(T_{3}\right)$ \\
\hline \multicolumn{7}{|l|}{ Normal } \\
\hline D. B. & 6.0 & 88 & 136 & 31.8 & 1.1 & 3.5 \\
\hline T. C. & 6.7 & 66 & 146 & 22.5 & 1.1 & 4.9 \\
\hline F. K. & 5.6 & 77 & 142 & 24.6 & 0.6 & 2.5 \\
\hline W. S. T. & 6.5 & 87 & 130 & 28.0 & 3.5 & 12.5 \\
\hline E. S. & 8.0 & 82 & 145 & 22.5 & 2.4 & 10.7 \\
\hline Mean \pm SD & $6.6 \pm 0.9$ & $80 \pm 9$ & $140 \pm 7$ & $25.9 \pm 4.0$ & $1.8 \pm 1.2$ & $6.9 \pm 4.4$ \\
\hline \multicolumn{7}{|l|}{ Before HD } \\
\hline W. S. & 5.4 & 59 & 72 & 12.2 & 5.2 & 42.6 \\
\hline W. A. & 4.3 & 43 & 55 & 5.6 & 1.2 & 21.4 \\
\hline D. M. & 5.2 & 53 & 88 & 13.7 & 5.8 & 42.3 \\
\hline M. A. S. & 3.4 & 41 & 58 & 9.0 & 2.5 & 27.8 \\
\hline Mean $\pm S D$ & $4.6 \pm 0.9$ & $49 \pm 9$ & $68 \pm 15$ & $10.1 \pm 3.6$ & $3.7 \pm 2.2$ & $33.5 \pm 10.5$ \\
\hline$P \ddagger$ & NS & NS & $<0.01$ & $<0.01$ & NS & $<0.01$ \\
\hline \multicolumn{7}{|l|}{ During HD } \\
\hline C. L. & 4.6 & 46 & 70 & 6.0 & 0.3 & 5.2 \\
\hline S. R. & 3.5 & 49 & 64 & 7.3 & 1.8 & 24.7 \\
\hline W. C. & 7.6 & 82 & 102 & 11.9 & 1.9 & 16.6 \\
\hline J. S. & 6.0 & 109 & 61 & 10.7 & 0.4 & 3.7 \\
\hline E. J. & 7.5 & 76 & 98 & 10.1 & 2.7 & 26.7 \\
\hline W. B. & 5.4 & 90 & 95 & 11.6 & 1.9 & 16.7 \\
\hline R. J. & 6.0 & 123 & 74 & 12.4 & 0.9 & 7.3 \\
\hline M. T. & 6.4 & 61 & 100 & 11.1 & 3.5 & 31.5 \\
\hline Mean \pm SD & $5.9 \pm 1.4$ & $81 \pm 26$ & $83 \pm 17$ & $10.1 \pm 2.3$ & $1.7 \pm 1.1$ & $16.6 \pm 10.5$ \\
\hline$P \ddagger$ & NS & NS & $<0.01$ & $<0.01$ & NS & NS \\
\hline \multicolumn{7}{|l|}{ After RT } \\
\hline J. R. & 4.1 & 67 & 120 & 19.6 & 7.7 & 39.3 \\
\hline R. T. & 8.1 & 89 & 112 & 16.4 & 1.4 & 8.5 \\
\hline M. S. & 7.0 & 88 & 145 & 28.1 & 6.2 & 22.1 \\
\hline S. W. & 7.2 & 68 & 148 & 28.1 & 1.5 & 5.3 \\
\hline N. G. & 8.0 & 64 & 125 & 25.3 & 0 & 0 \\
\hline Mean \pm SD & $6.9 \pm 1.6$ & $75 \pm 12$ & $130 \pm 16$ & $23.5 \pm 5.3$ & $3.4 \pm 3.3$ & $15.1 \pm 15.8$ \\
\hline$P \ddagger$ & NS & NS & NS & NS & NS & NS \\
\hline $\mathrm{F}$ ratio & 2.748 & 2.719 & 27.798 & 27.988 & 1.414 & 4.460 \\
\hline $\begin{array}{l}\text { Degree of } \\
\text { freedom }\end{array}$ & & & & & & \\
\hline$P$ & NS & NS & $<0.001$ & $<0.001$ & $\begin{array}{l}3 / 18 \\
\text { NS }\end{array}$ & $\begin{array}{l}3 / 18 \\
<0.05\end{array}$ \\
\hline
\end{tabular}

* The turnover rates (D) of $T_{4}$ and $T_{3}$ were calculated from the respective MCR determined during $\mathrm{L}-\mathrm{T}_{4}$ replacement and the $\mathrm{TT}_{4}$ and $\mathrm{TT}_{3}$ concentrations measured before $\mathrm{L}-\mathrm{T}_{4}$ treatment. The amount of $T_{3}$ secreted by the thyroid gland was derived from turnover rates of $T_{4}$ and $T_{3}$ and the percent of $T_{4}$ converted to $T_{3}$. Individual values from all four groups were analyzed by the analysis of variance and summarized as $\mathrm{F}$ ratio, degree of freedom, and $P$ values.

$\$$ The significance of the difference between the means of each patient group and the controls $(P)$ was derived by using the mean square within value. 
theoretically result from removal of circulating hormone through $\mathrm{HD}$, decreased $\mathrm{T}_{3}$-binding capacity, increased hormone catabolism, reduced thyroidal $\mathrm{T}_{3}$ secretion, and lastly, diminished extrathyroidal $\mathrm{T}_{4}$ to $\mathrm{T}_{3}$ conversion. The results of our studies provide evidence for the latter mechanism.

Peritoneal dialysis has been shown by Hermann et al. to be effective in removing $T_{4}$ in patients with thyrotoxic storm (8) and in rats made thyrotoxic by hormone administration (9). There are no data showing a decrease in serum $\mathrm{TT}_{4}$ after conventional $\mathrm{HD}$, using either cuprophane or cellulose membrane. Both Carter's report (15) and our study of the uremic patients before and 2 mo after institution of HD failed to show significant changes in the serum $\mathrm{TT}_{4}$ and FTI (Table II). On the contrary, serum-free $\mathrm{T}_{4}$ was reported to be higher after HD, an effect attributed to heparin $(7,35)$, which is known to alter hormone binding and increase the concentration of free $T_{4}(6)$.

Although we have not measured circulating free $\mathrm{T}_{3}$, Carter et al. (15), in a report of $\mathrm{T}_{3}$ deficiency syndrome associated with a variety of nonthyroidal diseases, including renal failure, found that free $T_{3}$ and $\mathrm{TT}_{3}$ were similarly decreased. Chopra et al. (16), in a study of the low $T_{3}$ syndrome with liver and kidney diseases, also reported that free $T_{3}$ was significantly reduced. Bermudez et al. (36) described 24 patients with decreased serum $T_{3}$ concentrations without thyroidal disease; 8 were due to low $\mathrm{T}_{3}$-binding capacity, 5 were attributable to their advanced age, and the remaining 11 were unexplained. Spector et al. reported that $54 \%$ of renal failure patients had low serum-free $\mathrm{T}_{3}$ concentrations (33). If our finding of low $\mathrm{TT}_{3}$ concentration was due entirely to decreased binding capacity, it should have affected $\mathrm{TT}_{4}$ to a greater extent. Furthermore, changes in TBG capacity were small and statistically not significant. The fact that $\mathrm{TT}_{4} / \mathrm{TT}_{3}$ ratio was markedly elevated in our patients suggests that factors other than low binding capacity must be responsible for the low $T_{3}$ deficiency.

Our kinetic studies showed that $\mathrm{T}_{3}$ degradation was not accelerated. In fact, the mean MCR was slightly decreased in both groups of uremic patients. As for the mean $\mathrm{T}_{3}$ secretion by the thyroid gland, it ranged only from 1.7 to $3.7 \mu \mathrm{g} /$ day in the four groups of subjects - representing only $7-14 \%$ of the total daily turnover in normal subjects. Hence, the observed depression in serum $\mathrm{TT}_{3}$ concentration cannot be explained on the basis of reduction, or even cessation, of thyroidal $T_{3}$ secretion. Actually, the mean percentage of thyroidal $T_{3}$ contribution to the overall amount of $\mathrm{T}_{3}$ metabolized was higher in patients with renal failure because of the marked reduction in their total $T_{3}$ turnover rate. The $\mathrm{T}_{3}$ degradation was drastically reduced to about $40 \%$ of control value. The mean percent of metabolized $\mathrm{T}_{4}$ converted to $\mathrm{T}_{3}$ was decreased to approximately one-third of normal. Since under our experimental conditions it could be assumed for practical purposes that the only source of $T_{3}$ was from extrathyroidal monodeiodination of $T_{4}$, these results indicate that uremic patients have a profound impairment in the ability to generate $T_{3}$ from $T_{4}$. This conclusion is in agreement with the observation that their serum $\mathrm{TT}_{3}$ remained subnormal when serum $\mathrm{TT}_{4}$ was raised after $\mathrm{L}-\mathrm{T}_{4}$ replacement.

Surks and co-workers have shown that a portion of radioiodine-labeled $T_{3}$ administered to animals or humans is present in serum and tissue in a TCAprecipitable but ethanol nonextractable form. It has turnover kinetics different from $\mathrm{T}_{3}$ and a more prolonged half-life of 14 days $(37,38)$. If not accounted for, especially in samples obtained 2 or more days after administration of the tracer, it may lead to falsely high ${ }^{131} \mathrm{I}-\mathrm{T}_{3}$ concentrations and consequently underestimation of MCR for $\mathrm{T}_{3}$. A comment is therefore in order to validate our $\mathrm{T}_{3}$ kinetic study, which did not take into account the nonextractable form of iodine. We believe that our observations are valid for several reasons: $(a)$ In the plotting and calculation of MCR, we used only samples obtained up to $48 \mathrm{~h}$ when nonextractable iodine represents a relatively small fraction of serum TCAprecipitable radioactivity. (b) The MCR of $\mathrm{T}_{3}$ (18.6 liters/day) in our control subjects was comparable to that reported by Nomura et al. (39), Surks et al. (19), and Inada et al. (40). (c) The magnitude of suppression of $\mathrm{T}_{3}$ turnover rate was so striking that even with a $10 \%$ correction for possible underestimation of MCR, the daily degradation would still be subnormal. Analogous to our results, in cirrhotic patients studied by Nomura et al. (39), MCR was only minimally decreased, but the $\mathrm{T}_{3}$ disposal rate was markedly reduced due to the low serum $\mathrm{TT}_{3}$ concentration.

Our studies do not indicate whether the defect in peripheral $T_{3}$ generation is due to the reduction of functioning renal tissue, to the metabolic derangement of uremia, or to the nonspecific effect of chronic illness. Experimental evidence of $T_{3}$ production from monodeiodination of $\mathrm{T}_{4}$ has been obtained in various tissues $(25,41,42)$, including the kidney (43). In our patients with renal failure, it does not appear that the conversion defect can be attributed to the lack of renal tissue, as serum $\mathrm{TT}_{3}$ concentration was not reduced further in anephric patients. A preponderant decrement in serum $\mathrm{TT}_{3}$ has been shown to occur in a variety of nonrelated chronic illnesses including liver cirrhosis, chronic obstructive pulmonary disease, disseminated malignancy, and malnutrition $(15,16$, $36,44)$. Diminished peripheral conversion of $T_{4}$ to $T_{3}$ is responsible for the decreased serum $\mathrm{TT}_{3}$ concentration in patients with liver failure (39) and starvation (45) and may be the common denominator in the selective $\mathrm{T}_{3}$ deficiency syndrome. 
In addition to the low serum $\mathrm{TT}_{3}$, uremia seems to be associated with other abnormalities of thyroid function, including slightly decreased $\mathrm{TT}_{4}$, high incidence of goiter, and abnormal TSH response to TRH. We found that serum $\mathrm{TT}_{4}$ concentrations, although within the normal range, tended to be lower than in controls, in agreement with the findings of other investigators $(5,14,33,46)$. Neuhaus et al. (46) attributed the low $\mathrm{TT}_{4}$ to decreased serum albumin and prealbumin. Joasso et al. (5) found that uremic patients had low serum $\mathrm{TT}_{4}$ and elevated $\mathrm{T}_{3}$ resin uptake, suggesting a decrease in TBG. However, actual measurement of TBG was normal. They postulated that uremic toxin(s) might have displaced $\mathrm{T}_{4}$ from TBG (5). In the 46 patients that we studied, only one had serum albumin lower than $3.5 \mathrm{~g} / 100 \mathrm{ml}$, and TBG capacity was not significantly different from normal. Of those patients whose TBG capacity was decreased, their $\mathrm{TT}_{4}$ was always low, but low $\mathrm{TT}_{4}$ was not necessarily accompanied by a reduction in TBG capacity, suggesting that factors other than decreased binding might, in part, be responsible for the slightly decreased serum $\mathrm{TT}_{4}$ concentration observed in some patients. Despite a marked reduction in the amount of $T_{4}$ converted to $T_{3}$ in patients with renal failure, the mean $T_{4} D$ was not decreased, indicating that other metabolic pathways of degradation were not inhibited. The possibility that monodeiodination occurred preferentially in the inner benzene ring, resulting in the formation of reverse $T_{3}$, should also be considered, as Chopra et al. (16) found that the serum reverse $T_{3}$ concentration was elevated in patients with renal failure.

A $37 \%$ incidence of goiter is considerably higher than expected for the Chicago area. Increased frequency of goiter in uremia was first described by Ramirez et al. (11) and was confirmed by Zerefos et al. (47) in an autopsy series. Thyroid enlargement could result from increased TSH stimulation related to excessive iodine accumulation, or the presence of goitrogenic substances. In a preliminary communication, we reported slightly elevated TSH levels in patients with renal failure (13), but we found subsequently that our anti-human TSH serum had considerable cross-reactivity with luteinizing hormone. Since we modified our assay procedures by prior absorption with human chorionic gonadotropins, the TSH values of our uremic patients had been consistently normal. Normal TSH values in renal failure were also reported by Silverberg et al. (14) and by Ramirez et al. (11).

Renal failure patients tend to retain iodide as shown by their high plasma inorganic iodide level $(1,2,14)$. Our finding of increased iodine content in the thyroid gland suggests that there might be a causal relationship between the high iodide stores and the increased incidence of goiter in uremia, particularly in the Chicago area, where the average dietary iodine intake is $420 \mu \mathrm{g} / \mathrm{day}^{2}{ }^{2}$ Ramirez et al. (11) proposed that retention of unknown goitrogens might be the explanation, and more recently Grantham et al. reported that aryl acid was markedly elevated in uremic patients and suggested that these aromatic compounds might be potentially goitrogenic $(34,48)$.

Although low $\mathrm{T}_{3}$ syndrome is now well recognized in uremia, its significance remains unclear. Assuming that $T_{3}$ is responsible for about one-half to two-thirds of the metabolic effects of the thyroid hormones (49), it is surprising that $T_{3}$ deficiency of the magnitude observed in our patients does not produce clinical hypothyroidism. In fact, studies designed to evaluate the metabolic effects of thyroid hormones in uremia have not revealed any abnormal results (33). Nevertheless, one should be cautious in interpreting some of these findings, since uremia per se or the presence of an arteriovenous fistula may alter some of the commonly used clinical tests of thyroid function such as basal metabolic rate and $\mathrm{QK}_{\mathrm{d}}$ interval measurements. The absence of TSH elevation is generally regarded as evidence against hypothyroidism, yet hypothalamo-pituitary dysfunction may also be present, as suggested by the subnormal TSH response to TRH. The delayed peak response and sustained elevation might be related to the decreased renal clearance of either TSH (50) or TRH (51). Blunted TSH secretion after TRH administration was also reported by Ramirez et al. (52), Alvarez-Ude et al. (53), and Czernichow et al. (54). Furthermore, abnormal prolactin (55) and growth hormone (56) secretion, as well as inadequate gonadotropin compensation (57), have been demonstrated in patients with renal insufficiency.

We have not fully assessed the functional integrity of the thyroid gland. The $\mathrm{T}_{3}$ increment of $20 \mathrm{ng} / 100 \mathrm{ml}$ or $28 \%$ after TRH administration was lower than that reported by Chopra et al. (58) in normal individuals, who at the end of $2 \mathrm{~h}$ had a mean $\mathrm{T}_{3}$ increment of $63 \mathrm{ng} / 100 \mathrm{ml}$ serum, representing a $70 \%$ rise over base line. The smaller rise in serum $\mathrm{TT}_{3}$ may not represent an intrinsic thyroid abnormality as their TSH response to TRH was subnormal. Ramirez et al. (52), however, reported that serum $\mathrm{TT}_{4}$ and $\mathrm{TT}_{3}$ increments after exogenous TSH administration were less than in controls, suggesting intrinsic thyroidal dysfunction.

After RT, serum thyroid hormone concentrations became normal. The rise in serum $\mathrm{TT}_{4}$ was in part due to higher TBG capacity while the increase in serum $\mathrm{TT}_{3}$ was due mostly to improved peripheral $\mathrm{T}_{4}$ to $\mathrm{T}_{3}$ conversion. The two patients whose $T_{3}$ turnover and $T_{4}$ to $T_{3}$ conversion rates were the lowest also had the

\footnotetext{
${ }^{2}$ Refetoff, S., and L. J. DeGroot. Unpublished observations.
} 
poorest renal function, their serum creatinine being $>2 \mathrm{mg} / 100 \mathrm{ml}$. With restoration of renal function, serum creatinine fell precipitously, but serum $\mathrm{TT}_{3}$ rose very slowly over a period of 3-4 mo. Before this, however, serum $\mathrm{TT}_{3}$ transiently decreased to below the pretransplant value, a possible consequence of the high-dose steroid treatment. Glucocorticoids are known to affect thyroid function by inhibition of extrathyroidal $\mathrm{T}_{4}$ to $\mathrm{T}_{3}$ conversion (59), decreased basal TSH secretion and TSH response to TRH stimulation $(60,61)$, and possibly suppression of TRH as well (62). When the dose of prednisone was tapered, circulating thyroid hormones gradually increased, but TSH response to TRH remained subnormal.

In summary, these studies indicate that uremia affects thyroid function at multiple levels: $(a)$ There is a blunted TSH response to TRH, suggesting pituitary dysfunction or hypersensitivity to hormonal feedback. (b) There may be an intrathyroidal defect in hormonogenesis, hormonal secretion, or both, as evidenced by high incidence of goiter, increased thyroidal iodine content, and, in some patients, low serum $\mathrm{TT}_{4}$ not accountable for by depressed TBG capacity. The subnormal $\mathrm{TT}_{4}$ response to exogenous $\mathrm{TSH}$ administration reported by Ramirez et al. (52) lends support to this possibility. (c) Abnormal peripheral metabolism is characterized by a profound impairment of $T_{4}$ to $T_{3}$ conversion in extrathyroidal tissues, which results in a selective and marked reduction in serum $\mathrm{TT}_{3}$ concentration. The metabolic significance of these abnormalities remains unclear and deserves further study.

\section{ACKNOWLEDGMENTS}

We are indebted to Dr. Leslie J. DeGroot for advice in the course of this work and for the review of the manuscript. We thank Mr. John Keck for assistance in statistical analysis. The technical assistance of Mr. Swen R. Hagen and Mr. Peter Lott are also acknowledged.

This work was supported in part by U. S. Public Health Service grants AM-15,070, and RR 55, University of Chicago Clinical Research Center, and RR 5476 and Medical Research Institute Council, Michael Reese Hospital.

\section{REFERENCES}

1. Beekers, C., C. Van Ypersele de Strihou, E. Coche, R. Troch, and P. Malvaux. 1969. Iodine metabolism in severe renal insufficiency. J. Clin. Endocrinol. Metab. 29: 293-296.

2. Koutras, D. A., S. G. Marketos, G. A. Rigpoulos, and B. Malamos. 1972. Iodine metabolism in chronic renal insufficiency. Nephron. 9: 55-56.

3. Robbins, J., and J. E. Rall. 1957. Hormone transport in circulation: The interaction of thyroid hormones and proteins in biological fluids. Recent Prog. Horm. Res. 13: $161-202$.

4. Refetoff, S., S. R. Hagen, and H. A. Selenkow. 1972. Estimation of the $T_{4}$ binding capacity of serum TBG and TBPA by a single $T_{4}$ load ion exchange resin method. J. Nucl. Med. 13: 2-12.

5. Joasso, A., I. P. C. Murray, J. Parkin, M. R. Robertson, and D. Jeremy. 1974. Abnormalities of in vitro thyroid function tests in renal disease. Q. J. Med. 43: 245-261.

6. Saeed-Uz-Zafar, M., J. M. Miller, G. M. Breneman, and J. Mansour. 1971. Observations on the effect of heparin on free and total thyroxine. J. Clin. Endocrinol. Metab. 32: 633-640.

7. Hershman, J. M., C. M. Jones, and A. L. Bailey. 1972. Reciprocal changes in serum thyrotropin and free thyroxine produced by heparin. J. Clin. Endocrinol. Metab. 34: 574-579.

8. Hermann, J., H. I. Krüskemper, K. O. Grosser, W. Hübner, and W. Böhm. 1971. Peritonealdialyse in der Behandlung der thyreotoxischen Ktise. Dtsch. Med. Wochenschr. 96: 742-745.

9. Hermann, J., H. J. Schmidt, and H. L. Krüskemper. 1973. Thyroxine elimination by peritoneal dialysis in experimental thyrotoxicosis. Horm. Metab. Res. 5: 180-183.

10. Wolff, J. 1969. Iodine goiter and pharmacological effects of excess iodide. Am. J. Med. 47: 101-124.

11. Ramirez, G., W. Jubiz, C. F. Gutch, H. A. Bloomer, R. Siegler, and W. J. Kolff. 1973. Thyroid abnormalities in renal failure: A study of 53 patients on chronic hemodialysis. Ann. Intern. Med. 79: 500-504.

12. Alexander, W. D., M. T. Harrison, R. McG. Harden, and D. A. Koutras. 1964. The effect of total fasting on thyroid function in man. Metab. Clin. Exp. 13: 587-590.

13. Lim, V. S., V. S. Fang, S. Refetoff, and A. I. Katz. 1974 $\mathrm{T}_{3}$ hypothyroidism in uremia. Proc. Am. Soc. Nephrol. 7: 52. (Abstr.).

14. Silverberg, D. S., R. A. Ulan, D. M. Fawcett, J. B. Dorsetov, M. Grace, and K. Beltcher. 1973. Effects of chronic hemodialysis on thyroid function in chronic renal failure. Can. Med. Assoc. J. 109: 282-286.

15. Carter, J. N., C. J. Eastman, J. M. Corcoran, and L. Lazarus. 1974. Effect of severe chronic illness on thyroid function. Lancet. II: 971-974.

16. Chopra, I. J., U. Chopra, S. R. Smith, M. Reza, and D. H. Solomon. 1975. Reciprocal changes in serum concentration of $3,3^{\prime}, 5^{\prime}$-triiodothyronine (reverse $T_{3}$ ) and 3,3'5-triiodothyronine $\left(\mathrm{T}_{3}\right)$ in systemic illness. J. Clin. Endocrinol. Metab. 41: 1043-1049.

17. Braverman, L. E., S. H. Ingbar, and K. Sterling. 1970. Conversion of thyroxine $\left(\mathrm{T}_{4}\right)$ to triiodothyronine $\left(\mathrm{T}_{3}\right)$ in athyreotic human subjects. J. Clin. Invest. 49: 855-864.

18. Pittman, C. S., J. B. Chambers Jr., and V. H. Read. 1971. The extrathyroidal conversion rate of thyroxine and triiodothyronine in normal man. J. Clin. Invest. 50: 1187-1196.

19. Surks, M. I., A. R. Schadlow, J. M. Stock, and J. H. Oppenheimer. 1973. Determination of iodothyronine absorption and conversion of L-thyroxine $\left(T_{4}\right)$ to $L$-triiodothyronine $\left(\mathrm{T}_{3}\right)$ using turnover rate techniques. J. Clin. Invest. 52: 805-811.

20. Robin, N. I., S. R. Hagen, F. Collaco, S. Refetoff, and H. A. Selenkow. 1971. Serum tests for measurement of thyroid function. Hormones (Basel). 2: 266-279.

21. Fang, V. S., and S. Refetoff. 1974. Radioimmunoassay for serum triiodothyronine $\left(T_{3}\right)$ : Evaluation of simple techniques to control interference from binding proteins. Clin. Chem. 20: 1150-1157.

22. Odell, W. D., P. L. Rayford, and G. T. Ross. 1967. Simplified, partially automated method for radioimmunoassay of human thyroid-stimulating, growth, luteinizing, and follicle-stimulating hormones. J. Lab. Clin. Med. 70: 973-980. 
23. Amino, N., S. R. Hagen, N. Yamada, and S. Refetoff. 1976. Measurement of circulating thyroid microsomal antibodies by the tanned red cell haemagglutination technique: Its usefulness in the diagnosis of autoimmune thyroid disease. Clin. Endocrinol. 5: 115-125.

24. Hoffer, P. B., A. Gottschalk, and S. Refetoff. 1972. Thyroid scanning technics: The old and the new. Curr. Prob. Radiol. 2: 1-26.

25. Refetoff, S., R. Matalon, and M. Bigazzi. 1972. Metabolism of L-thyroxine $\left(\mathrm{T}_{4}\right)$ and L-triiodothyronine $\left(\mathrm{T}_{3}\right)$ by human fibroblasts in tissue culture: Evidence for cellular binding proteins and conversion of $\mathrm{T}_{4}$ to $\mathrm{T}_{3}$. Endocrinology. 91: 934-947.

26. De Costre, P. U. Buhler, L. J. DeGroot, and S. Refetoff. 1971. Diurnal rhythm in total serum thyroxine levels. Metab. Clin. Exp. 20: 782-791.

27. Sterling, K., and R. B. Chodos. 1956. Radiothyroxine turnover studies in myxedema thyrotoxicosis and hypermetabolism without endocrine disease. J. Clin. Invest. 35: 806-813.

28. Oppenheimer, J. H., H. L. Schwartz, H. C. Shapiro, G. Bernstein, and M. I. Surks. 1970. Differences in primary cellular factors influencing the metabolism and distribution of 3,5,3'-L-triiodothyronine and L-thyroxine. J. Clin. Invest. 49: 1016-1024.

29. Oppenheimer, J. H., G. Bernstein, and J. Hasen. 1967. Estimation of rapidly exchangeable cellular thyroxine from plasma disappearance curves of simultaneous administered thyroxine- ${ }^{131} \mathrm{I}$ and albumin-125 I.J. Clin. Invest. 46: 762-777.

30. Sterling, K. 1951. The turnover rate of serum albumin in man as measured by 131 I-tagged albumin. J. Clin. Invest. 30: 1228-1237.

31. Weiner, B. J. 1962. In Statistical Principles in Experimental Design. McGraw-Hill, Inc., New York. 77-92.

32. Hays, M. T. 1968. Absorption of oral thyroxine in man. J. Clin. Endocrinol. Metab. 28: 749-756.

33. Spector, D. A., P. J. Davis, J. H. Helderman, B. Bell, and R. D. Utiger. 1976. Thyroid function and metabolic state in chronic renal failure. Ann. Intern. Med. 85: 724-730.

34. Grantham, J. J., J. B. Cohlmia, F. L. Whettier, and J. C. Meek. 1975. Hypothyroidism in patients with chronic renal disease. 6th International Congress of Nephrology. 618. (Abstr.)

35. DeVeber, G. A., and D. L. Schatz. 1969. Effects of hemodialysis on thyroid function. Proc. Eur. Dialysis Transplant Assoc. 5: 226-250.

36. Bermudez, F., M. I. Surks, and J. H. Oppenheimer. 1975. High incidence of decreased serum triodothyronine concentration in patients with nonthyroidal disease. J. Clin. Endocrinol. Metab. 41: 27-40.

37. Surks, M. I., and J. H. Oppenheimer. 1969. Formation of iodoprotein during the peripheral metabolism of 3,5,3'triiodo-L-thyronine-125 $\mathrm{I}$ in the euthyroid man and rat. J. Clin. Invest. 48: 685-695.

38. Surks, M. I., H. L. Schwartz, and J. H. Oppenheimer. 1969. Tissue iodoprotein formation during the peripheral metabolism of the thyroid hormones. J. Clin. Invest. 48: 2168-2175.

39. Nomura, S., C. S. Pittman, J. B. Chambers, Jr., M. W. Buck, and T. Shimizu. 1975. Reduced peripheral conversion of thyroxine to triiodothyronine in patients with hepatic cirrhosis. J. Clin. Invest. 56: 643-652.

40. Inada, M., K. Kasagi, S. Kurata, Y. Kazamb, H. Tokayama, L. Torizuka, M. Fukase, and T. Soma. 1975. Estimation of thyroxine and triiodothyronine distribution and of the conversion rate of thyroxine to triiodothyronine in man. J. Clin. Invest. 55: 1337-1348.

41. Sterling, K., M. A. Brenner, and V. F. Saldanha. 1973. Conversion of thyroxine to triiodothyronine by cultured human cells. Science (Wash.D.C.). 179: 1000-1001.

42. Rabinowitz, J. L., and E. S. Hercker. 1971. Thyroxine: Conversion to triiodothyronine by isolated perfused rat heart. Science (Wash. D. C.). 173: 1242-1243.

43. Albright, E. C., F. C. Larson, and R. H. Tust. 1954. In vitro conversion of thyroxine to triiodothyronine by kidney slices. Proc. Soc. Exp. Biol. Med. 86: 137-140.

44. Chopra, I. J., and S. R. Smith. 1974. Circulating thyroid hormones and thyrotropin in adult patients with proteincalorie malnutrition. J. Clin. Endocrinol. Metab. 40: 221-227.

45. Portnay, G., J. O’Brien, A. Vagenakis, M. Rudolph, R. Arky, S. Ingbar, and L. Braverman. 1974. Abnormalities in triiodothyronine metabolism induced by starvation in man. J. Clin. Invest. 53: 6la. (Abstr.)

46. Neuhaus, K., G. Baumann, H. Walser, and H. Tholen. 1975. Serum thyroxine and thyroxine-binding proteins in chronic renal failure without nephrosis. J. Clin. Endocrinol. Metab. 41: 395-398.

47. Zerefos, N. S., V. Jablokwo, M. M. Bartleson, V. Gandhi, and A. R. Lavender. 1974. Pathology of hemodialysis: A cardiovascular problem. Proc. Am. Soc. Nephrol. 7: 103. (Abstr.)

48. Porter, R. D., W. F. Cathcart-Rake, S. H. Wan, F. C. Whittier, and J. H. Grantham. 1975. Secretory activity and aryl acid content of serum, urine, and cerebrospinal fluid in normal and uremic man. J. Lab. Clin. Med. 85: $723-733$.

49. Sterling, K. 1970. The significance of circulating triiodothyronine. Recent Progr. Horm. Res. 25: 249-286.

50. Pokroy, H., S. Epstein, S. Hendricks, and B. Primstone. 1974. Thyrotropin response to intravenous thyrotropinreleasing hormone in patients with hepatic and renal failure. Horm. Metab. Res. 6: 132-136.

51. Cuttelod, S., T. Lemarchand-Beraud, P. Magnenat, C. Perret, S. Poli, and A. Vannotti. 1974. Effect of age and role of kidneys and liver on thyrotropin turnover in man. Metab. Clin. Exp. 23: 101-113.

52. Ramirez, G., W. O'Neil Jr., W. Jubiz, and H. A. Bloomer. 1976. Thyroid dysfunction in uremia: Evidence for thyroid and hypophyseal abnormalities. Ann. Intern. Med. 84: 672-676.

53. Alvarez-Ude, F., A. Gomez-Paz, D. C. Evered, A. Duns, R. Hull, and D. N. S. Kerr. 1975. Pituitary response to thyrotropin releasing hormone in patients with chronic renal failure. Proc. Int. Cong. Nephrol. 6th 883. (Abstr.)

54. Czemichow, P., M. C. Dauzet, M. Broyer, and R. Rappaport. 1976. Abnormal TSH, PRL, and GH response to TSH releasing factor in chronic renal failure. J. Clin. Endocrinol. Metab. 43: 630-637.

55. Nagel, T. C., N. Freinkel, R. H. Bell, H. Friesen, J. F. Wilber, and B. E. Metzger. 1973. Gynecomastia, prolactin, and other peptide hormones in patients undergoing chronic hemodialysis. J. Clin. Endocrinol. Metab. 36: 428-432.

56. Samaan, N. A., and R. M. Freeman. 1970. Growth hormone levels in severe renal failure. Metab. Clin. Exp. 19: $102-113$.

57. Lim, V. S., and V. S. Fang. 1975. Gonadal dysfunction in uremic men: A study of the hypothalamo-pituitarytesticular axis before and after renal transplantation. Am. J. Med. 58: 655-662.

58. Chopra, I. J., D. J. Solomon, U. Chopra, R. T. Young, and G. N. Chuatico. 1974. Alterations in circulating 
thyroid hormones and thyrotropin in hepatic cirrhosis: Evidence for euthyroidism despite subnormal serum triiodothyronine. J. Clin. Endocrinol. Metab. 39: 505511.

59. Duick, D. S., D. W. Warren, J. T. Nicoloff, C. L. Otis, and M. S. Croxson. 1974. Effect of single dose dexamethasone on the concentration of serum triiodothyronine in man.J. Clin. Endocrinol. Metab. 39: 1151-1154.

60. Otsuki, N., M. Dakoda, and S. Baba. 1973. Influence of glucocorticoids on TRH-induced $\mathrm{TSH}$ response in man. J. Clin. Endocrinol. Metab. 36: 95-102.

61. Sowers, J. R., H. E. Carlson, N. Brautbar, and J. M. Hershman. 1977. Effect of dexamethasone on prolactin and TSH responses to TRH and metoclopromide in man. J. Clin. Endocrinol. Metab. 44: 237-241.

62. Wilber, J. F., and R. D. Utiger. 1969. The effect of glucocorticoids on thyrotropin secretion. J. Clin. Invest. 48: 2096-2103. 